Arch. Tierz., Dummerstorf 44 (2001) S, 547-551

Agricultural University of Szczecin, Department of Genetics and Animal Breeding, Poland

MAREK KMIEĆ, ANDRZEJ DYBUS and ARKADIUSZ TERMAN

\title{
Prolactin receptor gene polymorphism and its association with lifter size in Polish Landrace
}

\begin{abstract}
Summary
Prolactin receptor gene (PRLR), which is localized on chromosome 16 in pigs, is a candidate gene marker for reproductive traits. The experiment was aimed to detect the DNA mutations in that gene and to find probable pedigree herd were studied. The polyme reproductive traits in Polish Landrace pigs. 207 sows and 8 boars from specific primers astered using PCR-RFLP method, with frequency of $P R L R^{A}$ was estimated at 0.44 and Two different alleles were identified: $P R L R^{4} ; P R L R^{\prime \prime}$. The genotypes $\mathrm{AA}, \mathrm{AB}$ and $\mathrm{BB}$ were $0.247,0.386$ and 0.367 . 0.56 . In the studied population of pigs frequencies of and teats number on the left and right between PRLR genolype age at the first parity were analyzed body side, total number of teats, number of piglets in the first litter and the The analysis showed the significant dependencies $(P \leq 0)$ fransformed from the discrete scale into the quantitative one. the genotype of prolactin ren the number of piglets in the firter and

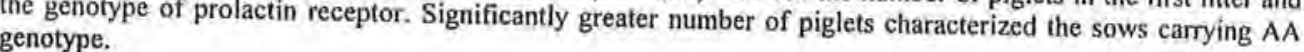

Key Words: Sus scrofa, pigs, Polish Landrace, prolactin receptor gene, PRLR, litter size

\section{Zusammenfassung} Titel der Arbeit: Zusammenhänge zwischen Polymorphismen im Prolaktinrezeptorgen und der Wurfgrösse

Das Prolaktinrezeptorgen (PRLR) wurde auf Chromosom 16 beim Schwein als Kandidatengen für Reproduktionsmerkmale lokalisiert. Das Ziel der Untersuchungen war der Nachweis von Zusammenhängen Untersuchungen wurden in einer Z PLR und untersuchten Reproduktionsmerkmalen bei Schweinen. Die Fbem Ebern bestand. Mittels PCR-RFLP wurde die Mutationsfrequenz im Prolaktinrezeptor bei Verwendung des Restriktionsenzyyms $A l u l$ bestimmt, Identifiziert wurden zwei Allele $P R L R^{A}$ und $P R L R^{\theta}$. PRLR trat mit der Frequenz 0,440 auf, $P R L R^{B}$ mit 0,560. In der Schweinepopulation kamen die Genotypen $A A, A B$ und $B B$ mil der Frequenz entsprechend $0,247,0,386$ und 0,367 vor. Analysiert wurde die Abhängigkeit zwischen dem Genotyp PRLR und der AnzahI der links und rechts gelegenen Zitzen, der Gesamtzahl der Zitzen, der Anzahl der geborenen Ferkel im 1. Wurf und dem Wurfalter. Die Ausgangsdaten der diskreten Verteilung wurden aus der diskreten Skala in die qualitative transformiert. Die durchgefuhrte Analyse zeigte die relevanten Abhängigkeiten zwischen der Anzahl der geborenen Ferkel im 1. Wurf und den PRLR Genotypen. Die höhere Zahl an Ferkel stammte von Sauen mit dem Genotyp AA.

Schlusselworter: Sus scrofa, Polnische Landrasse, Prolaktinrezeptorgen (PRLR), Wurfgrösse

\section{Introduction}

The reproduction, particularly in the species having large litters, plays an important role in the successful production of farm animals. The cost of one piglet rearing decreases according to the increasing number of piglets in one litter. The genes encoding hormone proteins influence the metabolism and, in the result, the productivity of animals, so they can be very useful in performance traits improvement. 
The gene of prolactin receptor (PRLR), which is mapped to chromosome 16 in pigs (VINCENT et al., 1997), is such a candidate gene for reproductive traits in six PIC lines (Large White, Landrace, Duroc, Landrace $x$ Pietrain and Large White $x$ Chinese Meishan). The PRLR gene evidently affected the number of piglets born alive. In the first litters, its effect was estimated at 0,25 piglet per litter (ROTHSCHILD et al., 1998). However, there is still insufficient information about phenotypic effects of PRLR gene in many lines and races of pigs.

The presented study was aimed to estimate the frequency of $P R L R$ gene mutation and to find possible relations between PRLR genotype and reproductive traits in the herd of Polish Landrace sows.

\section{Material and methods}

The experiment covered 207 sows and 8 boars - reproducers came from pedigree herd of Polish Landrace breed in one farm in Western Pomerania. The studied sows were bred form 40 boars, which were not related to each other.

The genotype of prolactin receptor was established using PCR - RFLP method. 457 base pair long fragment of PRLR DNA was amplified with primers of sequences proposed by VINCENT et al,, 199]: forward 5' - CCC AAA ACA GCA GGA GGA CG -3' and the reverse 5' - GGC AAG TGG TTG AAA ATG GA - 3'. The PCR reactions were carried out in Perkin Elmer thermocycler in a volume of $25 \mu \mathrm{l}$ containing $100 \mathrm{ng}$ of template DNA, 15 pmol of each primer, each dNTP at $100 \mu \mathrm{M}$, $1,5 \mathrm{mM} \mathrm{MgCl}_{2}, 10 \mathrm{mM}$ Tris- $\mathrm{HCl}(\mathrm{pH} 8,3), 50 \mathrm{mM} \mathrm{KCl}$, and 0,6 units Taq DNA polymerase (MBI Fermentas). Cycling conditions were $94^{\circ} \mathrm{C} / 5 \mathrm{~min}$ followed by 35 cycles of $40 \mathrm{~s}$ at $94^{\circ} \mathrm{C}, 40 \mathrm{~s}$ at $60^{\circ} \mathrm{C}, 40 \mathrm{~s}$ at $72^{\circ} \mathrm{C}$ and final $5 \mathrm{~min}$ at $72^{\circ} \mathrm{C}$.

PCR product was than digested with 6 units of restriction enzyme AluI (MBI Fermentas), 3 hours at $37^{\circ} \mathrm{C}$. The restriction fragments were separated in $5 \%$ agarose gel electrophoresis (PRONA) and stained with ethidium bromide. The results were visualized in UV rays.

Performance traits data were collected from farm documentation and they contained the teats number on the left and right body side, total teats number, piglets number in the first litter (boar and sow piglets) and sow age at the first farrowing. The mean age of first farrowing, in studied sows, was 359 days. The number of teats and piglets was transformed from the discrete scale into quantitative one, according to SNELL procedure (1964), then those data were corrected for the year of birth, using correction factors (ZUK, 1989), before the analysis was done. The relations between PRLR genotype and studied reproductive traits were analyzed with one-way analysis of variance and the significance of differences was verified using Duncan test with computer program Statistica'99.

\section{Results and discussion}

Prolactin is one of the protein hormones released by pituitary gland, which control reproductive processes. The signals of prolactin are recognized by specific receptors (PRLR) built into cell membranes. Detection of the polymorphism of PRLR gene could increase improving the reproductive traits in farm animals.

In the herd of studied pigs, two different alleles of PRLR gene were identified with PCR - RFLP method: allele A and B that were responsible for three different 
genotypes: $\mathrm{AA}, \mathrm{AB}$ and $\mathrm{BB}$. The lengths of restriction fragments detected during the experiment were as follows: 124, 110, 79, 77 and 67 base pair (bp) for allele $A$ and 124, 90, 79, 77, 67 and 20 bp for B one (Fig.). The frequency of allele A was estimated at 0,440 , while of allele B $-0,560$ (Table 1). However, VINCENT et al., 1997 reported the frequency of allele A in different pig breeds: Chester White $(n=10)-0.25$; Duroc $(\mathrm{n}=10)-0.79$; Hampshire $(\mathrm{n}=10)-0.05$; Landrace $(\mathrm{n}=9)-0.72$; Yorkshire $(\mathrm{n}=$ 12) -0.37 ; Chinese Meishan $(n=9)-0.56$ and European Large White $(n=11)-0.32$. Among the population of studied pigs, genotype AA was detected with the frequency of $0.247, \mathrm{AB}-0.386$ and $\mathrm{BB}-0.367$. In the herd of sows, the frequency of $P R L R$ genotype $\mathrm{AA}$ was twice as high as in the group of 8 boars $(0.251$ and 0.125 respectively). However, the frequency of $\mathrm{AB}$ genotype (0.382) and $\mathrm{BB}$ one (0.367) in sows was not significantly lower than in boars $(\mathrm{AB}-0.5$ and $\mathrm{BB}-0.375$ (Table 1$)$.

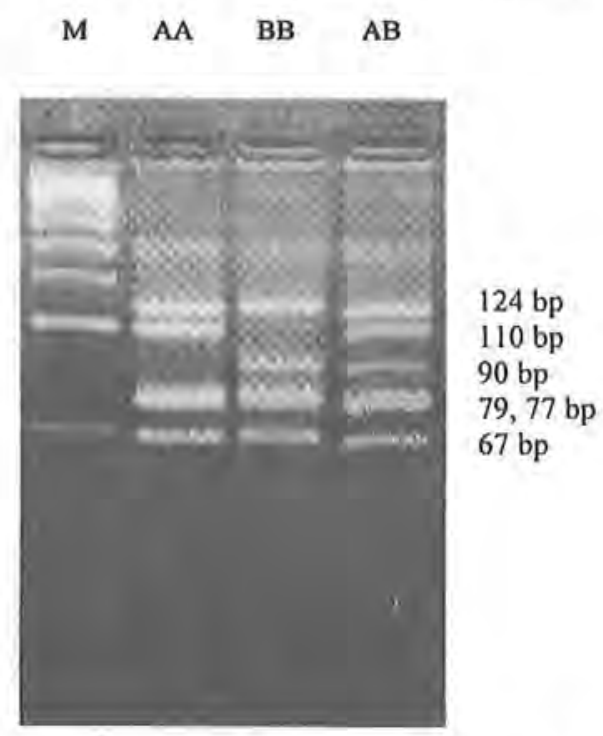

Figure: PCR - RFLP products of porcine PRLR gene. The figure shows three different genotypes: $A A, A B$ and BB. M-DNA marker pUC19/MspI (PCR-RFLP Produkte des Gens. Das Foto stellt vor: AA, AB und BB. M - DNA Marker pUC19/MspI)

Table 1

The frequency of genotypes and alleles of PRLR gene in studied population of pigs (Frequenz der Genotypen und Allele des Prolaktinrezeptors (PRLR) in der untersuchten Schweineherde)

\begin{tabular}{|c|c|c|c|c|c|c|c|}
\hline \multicolumn{2}{|c|}{ Group } & \multicolumn{3}{|c|}{ PRLR genotype } & \multirow{2}{*}{ Total } & \multicolumn{2}{|c|}{$P R L R$ allele } \\
\hline & & AA & $\mathrm{AB}$ & BB & & $\mathrm{A}$ & B \\
\hline \multirow[t]{2}{*}{ Boars } & $\mathbf{n}$ & 1 & 4 & 3 & 8 & \multirow{2}{*}{0.375} & \multirow{2}{*}{0.625} \\
\hline & Frequency & 0.125 & 0.500 & 0.375 & 1.000 & & \\
\hline \multirow[t]{2}{*}{ Sows } & $\mathrm{n}$ & 52 & 79 & 76 & 207 & \multirow{2}{*}{0.442} & \multirow{2}{*}{0.558} \\
\hline & Frequency & 0.251 & 0.382 & 0.367 & 1.000 & & \\
\hline \multirow[t]{2}{*}{ Total } & n & 53 & 83 & 79 & 215 & \multirow{2}{*}{0.440} & \multirow{2}{*}{0.560} \\
\hline & Frequency & 0.247 & 0.386 & 0.367 & 1.000 & & \\
\hline
\end{tabular}


In the analyzed herd of sows, deviation from genetic equilibrium was observed between the observed and expected numbers of $\operatorname{PRLR}\left(\chi^{2}=10.020 ; \mathrm{P} \leq 0.01\right)$. Comparing the observed and the expected numbers of particular PRLR genotypes, it was demonstrated that genotype $P R L R$ AB occurred significantly $(\mathrm{P} \leq 0.05)$ more frequently, than it would be expected on the basis of the Hardy-Weinberg equilibrium.

The analysis of the teats number on the left and right body side and total teats number showed small and statistically not significant differences between sows carrying different PRLR genotypes. The greatest total number of teats was counted in sows with $\mathrm{BB}$ genotype (15.44), a little smaller - AB genotype (15.38) and the smallest - AA one (15.33) (Table 2).

Table 2

Means and standard deviation of teats number in sows carrying different PRLR genotypes (Mittlere Standardabweichung der Zitzenanzahl bei Sauen verschiedener Genotypen des Prolaktinrezeptors (PRLR))

\begin{tabular}{ccccccccc}
\multirow{2}{*}{$\begin{array}{c}P R L R \\
\text { genotype }\end{array}$} & $\begin{array}{c}\text { Number } \\
\text { of } \\
\text { sows }\end{array}$ & $\begin{array}{c}\text { Number left } \\
\text { side teats }\end{array}$ & \multicolumn{2}{c}{$\begin{array}{c}\text { Number right } \\
\text { side leats }\end{array}$} & \multicolumn{2}{c}{$\begin{array}{c}\text { Total number } \\
\text { of teats }\end{array}$} \\
\cline { 3 - 8 } AA & 52 & Mean & SD & Mean & SD & Mean SD & SD \\
\hline AB & 79 & 7.54 & 0.54 & 7.46 & 0.50 & 15.33 & 0.71 \\
\hline BB & 76 & 7.61 & 0.52 & 7.35 & 0.51 & 15.38 & 0.76 \\
\hline Total & 7.57 & 0.50 & 7.34 & 0.48 & 15.44 & 0.70 \\
\hline
\end{tabular}

Table 3

The number of piglets in the first litter of sows with different PRLR genotypes (Anzahl der im I. Wurf geborenen Ferkeln bei Sauen von verschiedenen Genotypen des Prolaktinrezeptors (PRLR))

\begin{tabular}{|c|c|c|c|c|c|c|c|c|}
\hline \multirow[t]{2}{*}{$\begin{array}{c}\text { PRLR } \\
\text { genotype }\end{array}$} & \multirow{2}{*}{$\begin{array}{c}\text { Sows } \\
\text { number }\end{array}$} & \multicolumn{2}{|c|}{$\begin{array}{l}\text { Number } \\
\text { of piglets }\end{array}$} & \multicolumn{2}{|c|}{$\begin{array}{c}\text { Number } \\
\text { of boar piglets }\end{array}$} & \multicolumn{2}{|c|}{$\begin{array}{c}\text { Number } \\
\text { of sows piglets }\end{array}$} & $\begin{array}{c}\text { The age of the } \\
\text { first parity } \\
\text { [days] }\end{array}$ \\
\hline & & Mean & SD & Mean & SD & Mean & SD & Mean SD \\
\hline $\mathrm{AA}$ & 116 & $10.51^{\wedge}$ & 1.10 & 6.08 & 3.11 & $5.99 ?$ & 2,22 & $356.8 \quad 49.6$ \\
\hline $\mathrm{AB}$ & 84 & 10.44 & 0.99 & 6.76 & 3.51 & $5.47:$ & 3.09 & $360.0 \quad 51.8$ \\
\hline $\mathrm{BB}$ & 62 & $10.16^{\wedge}$ & 0.88 & 6.42 & 2.77 & 5,14 & 2.51 & $358.1 \quad 55.0$ \\
\hline Total & 207 & 10.43 & 1.25 & 6.46 & 3.15 & 5.422 & 2.69 & $358.5 \quad 52.2$ \\
\hline
\end{tabular}

Table 3 shows the number of piglets in the first litter of Polish Landrace sows and the sow age at the first farrowing relating to PRLR genotype. The greatest mean number of piglets in the first litter characterized sows with AA genotype (10.51), while AB sows 
had 10.44 piglets and BB 10,16. The difference between pigs carrying genotypes AA and $\mathrm{BB}$ was 0.35 piglet per litter and was statistically significant at 0.1 level. In 1998 , Rothschild obtained similar results (ROTHSCHILD et al., 1998); the effect of PRLR genotype was 0.25 piglet per litter but in successive litters that effect was greater.

The differences observed between animals with different PRLR genotypes were small and statistically not significant.

\section{Conclusions}

Two alleles of prolactin receptor gene and three genotypes $(A A, A B$ and $B B$ ) were identified in the analyzed herd of Polish Landrace. The frequency of allele A was 0.44 and $\mathrm{B}-0.56$. The genotype $\mathrm{AA}$ was present with the frequency 0.47 , genotype $\mathrm{AB}-$ 0,386 and $\mathrm{BB}-0.67$.

The analysis of relation between the genotype of prolactin receptor and the studied reproductive traits showed significantly greater $(P \leq 0.1)$ mean number of piglets in the first litter ( 0.5 piglet more) of sows carrying AA genotype then $B B$ one.

The analysis of the teats number on the left and right body side and total teats number showed small and statistically not significant differences between sows carrying different $P R L R$ genotypes. The greatest total number of teats was counted in sows with $\mathrm{BB}$ genotype (15.4), a little smaller - $\mathrm{AB}$ genotype (15.8) and the smallest - AA one (I5.3).

\section{References}

ROTHSCHILD, M.F.; VINCENT, A.L.; TUGGLE, C.K.; EVANS, G.; SHORT, T.H.; SOUTHWOOD, O.1.; WALES, R.; PLASTOW, G.S.

SNELL, E.J.

A mutation in the prolactin receptor gene in associated with increasing litter size in pigs. Animal

A scaling procedure for ordered categorical data. Biometrics, 9 (1964), 592-607

VINCENT, A.L.; WANG, L.; TUGGLE, C.K.; ROBIC, A.; ROTHSCHILD, M.F.; ZUK, B.:

Prolactin receptor maps pig chromosome I6. Mammalian Genome, 8 (I997) 10, 793 - 794

Practical biometrics. (Polish Language). PWN Warszawa, 1989

Received: 2000-10-09

Accepted: $2001-06-18$

Authors' address

PhD DSc Prof, MAREK KMIEĆ, MSc ANDRZEJ DYBUS, MSc ARKADIUSZ TERMAN

Agricultural University of Szczecin

Department of Genetics and Animal Breeding

ul. Doktora Judyma 6

$71-460$ Szczecin

Poland 


\title{
Buchbesprechung
}

\author{
Gesunde Rinderbestånde durch Homo̊opathie
}

\section{CHRISTOPHER DAY}

175 Seiten, Sonntag Verlag, Stuttgart, 2001. ISBN 387758 IS5 2, DM 59,0; 8S 431,0; sFr 52,50

Aus dem Englischen Ubersetzl und bearbeitet von A. SCHMIDT, dem Autor des im gleichen Verlages erschienenen Buches ",Grundkurs in klassischer Homöopathie fur Tierärzte", liegt dieser praktische Leitfaden zum Einsatz der Homöopathie in der Rinderhaltung vor. Dieses Buch liegt wie andere auf diesem Gebiet in jüngerer Zeit erschienene Titel im Zeittrend, welcher vermehrt ,nicht chemische" Therapien fordert. Die Zahl von Tierärzten, die eine komplementärmedizinische Erweiterung ihrer Therapiemöglichkeiten suchen, wird größer. Es steigt auch nicht nur die Nachfrage nach hombopathischen Behandlungen aus den Reihen des ökologischen Landbaues, sondern auch bei Tierhaltern, die z.B. bei chronischen Erkrankungen Alternativen zu den bisherigen konventionellen Möglichkeiten suchen. Begrußenswert ist in vorliegendem Titel das Bemühen des Autors Homöopathie nicht nur als Alternative, als Ersatz schulmedizinischer Therapien zu sehen, sondern auch als sinnvolie Ergänzung in der veterinärmedizinischen Praxis. Mit dem Ziel der Praxistauglichkeit wollte der Autor ein gut handhabbares, informatives Kompendium für Tierärzte und Landwirte vorzulegen.

Die einfilhrenden Abschnitte zeigen die Komplexität hombopathischer Methoden und sind für das Verstándnis der Wirkprinzipien unerlasslich. U.a. wird dargelegt, dass Homøopathie eine Regulierungstheraphie ist, welche fehlgewordene Anpassungsflhigkeit des Organismus im Sinne der Selbstheilung korrigiert bzw. fordert. Es werden u.a. die Grïnde für die Anwendung der Homöopathie besprochen aber auch die Grenzen bzw. der notwendige Ruckgriff auf konventionelle Medikamente diskutiert. Weitere Abschnitte behandeln die verschiedenen Vorgehensweisen sowie die Anwendung der Arzneien, ihre Zubereitung, Dosicrung, Verabreichung u.a.. In sorgfaltiger Auswahl folgt ein Arzneimittelverzeichnis und die Beschreibung verschiedener Arzneien, die in der Rinderpraxis zur Anwendung kommen. In alphabetischer Reihenfolge werden die wichtigsten beim Rind auftretenden Krankheiten, die dazu passenden Arzneien sowie die bewăhrten homơopathischen Vorgehensweisen besprochen, wobei je nach Wichtigkeit bestimmte Arzneien drucktechnisch besonders gekennzeichnet sind. Es folgen Abschnitte die Vorgehensweisen bei psychischen Störungen empfehlen, die das Wohlbefinden der Tiere befördern oder vorbeugende Maßnahmen bei der Mastitis beschreiben. Informativ ist auch die Darstellung von Fallbeispielen. Den Abschluss bilden Vorschlage für eine Stallapotheke, ein Glossar, eine Arzneicheckliste, weiterfuhrende Literatur, nutzliche Adressen und ein Arzneimiltelverzeichnis.

Das sehr anwendungsorientierte, praxisrelevante Buch macht aber auch deutlich, dass Homöopathie tierărztliches Wissen und Können, Beobachtungsgabe sowie die Fáhigkeit zur Deduktion von Befunden und deren richtige Interpretation erfordert. Es informiert den Tierhalter aber Moglichkeiten alternativer Prophylaxe und Therapie und kann helfen die Zusammenarbeit zwischen Tierhaltem und Tierürten effektiver zu gestalten. 